\title{
Emergency obstetric hysterectomy: review at a tertiary care hospital
}

\author{
Shirodker S. D., Ankita Pandey*, Sunil Yadav
}

Department of Obstetrics and Gynecology, TNMC and BYL Nair Hospital, Mumbai, Maharashtra, India

Received: 11 August 2016

Revised: 20 August 2016

Accepted: 21 September 2016

\section{*Correspondence:}

Dr. Ankita Pandey,

E-mail: sonamnrs86@gmail.com

Copyright: (c) the author(s), publisher and licensee Medip Academy. This is an open-access article distributed under the terms of the Creative Commons Attribution Non-Commercial License, which permits unrestricted non-commercial use, distribution, and reproduction in any medium, provided the original work is properly cited.

\section{ABSTRACT}

Background: The objective of the study was to study indications and maternal outcome of emergency obstetric hysterectomy.

Methods: A retrospective study of the cases of emergency obstetric hysterectomy performed over a period of 7.5years from 2008 to May 2016 in a tertiary care hospital was done. Maternal characteristics, indications, and maternal morbidity and mortality were analyzed.

Results: During the study period there were 45 emergency obstetric hysterectomies and 28,207 deliveries, giving an incidence of $0.16 \%$ or $1.6 / 1000$. Majority of the cases were unbooked (55.6\%). It was more common in multipara $(71.1 \%)$. Ruptured uterus $(37.7 \%)$ and morbidly adherent placenta $(26.6 \%)$ were the common indications. the maternal mortality was $2.22 \%$.

Conclusions: Emergency obstetric hysterectomy is a lifesaving procedure. The maternal outcome greatly depends on timely decision and good clinical judgment because unnecessary delay can cost life and undue haste can cause morbidity.

Keywords: Obstetric hysterectomy, Emergency obstetric hysterectomy, Morbidly adherent placenta

\section{INTRODUCTION}

Emergency obstetric hysterectomy $(\mathrm{EOH})$ is defined as extirpation of the uterus either at the time of cesarean section or following vaginal delivery, or within the puerperium period. It is usually performed in the face of unrelenting and life-threatening obstetric hemorrhage. A near miss event is defined as a woman who nearly died but survived a complication that occurred during pregnancy, childbirth, or within 42 days of termination of pregnancy. ${ }^{1}$ EOH can be rightly classified as a near miss event. It is important to study such events since they provide an insight into the standard of care provided and help to reduce maternal morbidity and mortality. Conservative methods such as community-based use of misoprostol, oxytocin, condom catheter balloon, and noninflatable anti-shock garments for the management of hypovolemic shock have all been advocated to effectively manage obstetric hemorrhage in low resource settings. ${ }^{2}$ Advances in interventional radiology have also provided the option of uterine artery embolization. ${ }^{3,4}$

While this does seem encouraging, with regard to clinical implications, hemorrhage continues to be the leading individual cause of maternal death worldwide accounting for $27.1 \%$ of deaths as recently as $2014 .^{5}$ In this analysis, India and Nigeria together accounted for a third of global maternal deaths ${ }^{5}$. More alarming is the fact that some studies from developed nations are pointing towards an increase in the rate of postpartum haemorrhage. ${ }^{6}$ One meta-analysis reported an annual increase of $8 \%$ in the incidence of EOH around the world. ${ }^{7}$

In no other gynaecological or obstetrical surgery is the surgeon in as much a dilemma as when deciding to resort to an emergency hysterectomy. On one hand it is the last 
resort to save a mother's life, and on the other hand, the mother's reproductive capability is sacrificed. Many times it is a very difficult decision and requires good clinical judgement. Most of the times the operation is carried out when the condition of the patient is too critical to withstand the risks of anesthesia or surgery. Proper timing and meticulous care may reduce or prevent maternal complications.

\section{METHODS}

A retrospective analysis of 45 cases of emergency hysterectomies done for obstetric indications over a period of 7.5 years from 2008 to May 2016 was done. Maternal characteristics, indications for hysterectomy, and causes of maternal morbidity and mortality were studied. Hysterectomy for any indication during pregnancy, labor and puerperium has been included. Each case record was analyzed in details with special emphasis on indication, demographic data (age, parity, booked or emergency case etc.), type of operation performed (subtotal or total obstetric hysterectomy), problems encountered during operation, morbidity and mortality.

\section{RESULTS}

\section{Incidence}

There were 45 cases of emergency hysterectomies amongst 28,207 deliveries during the period of study giving an incidence of $0.16 \%$ i.e. 1 in 625 deliveries.

\section{Maternal Characteristics}

A) Age: Forty four percent of the women were in the age group of 26-30 years (Table 1).

Table 1: Age distribution.

\begin{tabular}{|lll|}
\hline Age & No. & Percentage \\
\hline$<20$ & 2 & $4.4 \%$ \\
\hline $21-25$ & 13 & $28.8 \%$ \\
\hline $26-30$ & 20 & $44.4 \%$ \\
\hline $31-35$ & 8 & $17.7 \%$ \\
\hline$>35$ & 2 & $4.4 \%$ \\
\hline
\end{tabular}

B) Parity: $28.8 \%$ women were primiparous while $71.1 \%$ were multipara (Table 2).

Table 2: Parity distribution.

\begin{tabular}{|lll|}
\hline Parity & No. & Percentage \\
\hline Primiparous & 13 & $28.8 \%$ \\
\hline Multipara & 32 & $71.1 \%$ \\
\hline
\end{tabular}

C) Antenatal booking: Twenty five cases were not booked $(55.5 \%)$ and twenty booked $(44.4 \%)$ for delivery (Table 3).
Table 3: Antenatal booking.

\begin{tabular}{|lll|}
\hline Booking status & No. & Percentage \\
\hline Registered & 20 & $44.4 \%$ \\
\hline Unregistered & 25 & $55.5 \%$ \\
\hline
\end{tabular}

D) Indications: Ruptured uterus (37.7\%) and morbidly adherent placenta $(26.6 \%)$ were the common indications (Table 4).

Table 4: Indication of hysterectomy.

\begin{tabular}{|lll|}
\hline Indication of hysterectomy & $\begin{array}{l}\text { No. of } \\
\text { cases }\end{array}$ & Percentage \\
\hline Rupture uterus & 17 & $37.7 \%$ \\
\hline Atonic PPH & 10 & $22.2 \%$ \\
\hline Morbidly adherent placenta & 12 & $26.7 \%$ \\
\hline Retained placenta & 2 & $4.4 \%$ \\
\hline Cervical tear & 1 & $2.2 \%$ \\
\hline Accidental haemorrhage & 1 & $2.2 \%$ \\
\hline Secondary PPH & 2 & $4.4 \%$ \\
\hline
\end{tabular}

\section{Type of operation}

In $62 \%$ of the cases, subtotal hysterectomy was performed. It is not always possible to do total abdominal hysterectomy as the patients' general condition is often poor. It is important to ligate the stumps doubly and carefully, as tissues are more vascular and edematous. Altered coagulation often contributes to more bleeding.

\section{Additional surgical procedure}

Internal iliac artery ligation was done in 14 cases. Repair of a tear in the bladder was required in one case.

\section{Post-operative Complications}

Table 5 shows that $26.6 \%$ of cases suffered from febrile morbidity.

Table 5: Post-operative complications.

\begin{tabular}{|lll|}
\hline Causes & No. of cases & Percentage \\
\hline Febrile morbidity & 12 & $26.6 \%$ \\
\hline Septicemia & 7 & $15.5 \%$ \\
\hline Wound infection & 5 & $11.1 \%$ \\
\hline Bladder injury & 1 & $2.2 \%$ \\
\hline Fistula & 0 & 0 \\
\hline mortality & 1 & $2.2 \%$ \\
\hline
\end{tabular}

There was one maternal death giving a maternal mortality of $2.22 \%$. It was due to DIC with septicemia with multi organ dysfunction. All our patients received blood transfusion and $>98 \%$ had over 5-7 units of blood. 


\section{DISCUSSION}

Cesarean hysterectomy still remains a necessary tool for the obstetrician. Knowledge of this operation and skill at its performance saves lives in catastrophic rupture of the uterus or intractable PPH. There has been an upsurge in cases of postpartum hemorrhage requiring hysterectomy ${ }^{8}$ primarily due to the changed settings in which postpartum hemorrhage presents itself in modern obstetrics. Despite wider availability of contraceptives and abortion services, and reduced family size the world over, there has been a consistent rise in the rates of cesarean section attributable, in part, to patient preferences and medico-legal implications on medical fraternity. Additionally, advances in anesthesia, blood bank facilities, and intensive care back-up have made it a safer and painless alternative to labor. This has not only given rise to a surge in complications like abnormal placentation and uterine rupture, but also in the incidence of atonic postpartum hemorrhage. This is why EOH has become increasingly relevant in modern obstetric practice. An analysis of patient discharge notes in Canada has revealed a rise in the rate of postpartum hemorrhage necessitating hysterectomy. ${ }^{8}$

Incidence of emergency hysterectomy in the present study was $0.16 \%$ which is higher than that in many other studies (Table 6) because our institution is an important referral center in this region and most of our cases were referred from outside in moribund condition after complications occurred.

Table 6: Comparative incidence of obstetric hysterectomy.

\begin{tabular}{|llll|}
\hline $\begin{array}{l}\text { Name of } \\
\text { study }\end{array}$ & incidence & $\begin{array}{l}\text { Common } \\
\text { indication }\end{array}$ & $\begin{array}{l}\text { Maternal } \\
\text { mortality }\end{array}$ \\
$\begin{array}{l}\text { Forna } \mathrm{F}^{11} \\
(2004)\end{array}$ & $0.08 \%$ & Atonic PPH & \\
\hline $\begin{array}{l}\text { Kant and } \\
\text { Wadhwani } \\
(2005)\end{array}$ & $0.26 \%$ & Atonic PPH & $9.70 \%$ \\
\hline $\begin{array}{l}\text { Ahmad and } \\
\text { Mir }^{13}(2007)\end{array}$ & $0.26 \%$ & $\begin{array}{l}\text { Rupture } \\
\text { uterus }\end{array}$ & $3 \%$ \\
\hline $\begin{array}{l}\text { Marwaha P } \\
\text { et al }\end{array}{ }^{14}(2008)$ & $0.31 \%$ & $\begin{array}{l}\text { Rupture } \\
\text { uterus }\end{array}$ & $10 \%$ \\
\hline $\begin{array}{l}\text { Flood et al } \\
(2008)\end{array}$ & $0.04 \%$ & $\begin{array}{l}\text { Increasing } \\
\text { incidence } \\
\text { of MAP }\end{array}$ & - \\
\hline $\begin{array}{l}\text { Sharma et } \\
\text { al }^{16}(2009)\end{array}$ & $0.54 \%$ & \begin{tabular}{l} 
Atonic PPH \\
\hline $\begin{array}{l}\text { Temizkan } \\
\mathrm{O}^{17}(2016)\end{array}$
\end{tabular} & $5.7 \%$ \\
\hline
\end{tabular}

Ruptured uterus is the most common indication in our study accounting for $36.58 \%$ of cases. Majority of cases of ruptured uterus were referrals from distant peripheral hospitals. This is comparable to study by Ahmad and Mir and Marwaha P et al. ${ }^{13,14}$

Morbidly adherent placenta accounted for $26.6 \%$ of cases which implies increasing incidence of primary caesarean sections, reduction of them might decrease the incidence of adherent placentae. There has been a significant change in the indication of EOH over time and from one region to another. Traditionally, uterine atony was the most common indication for hysterectomy. Recent studies have indicated that abnormal placentation is replacing uterine atony as the most common indication for EPH. In our case, morbidly adherent placenta was the second most common indication for EOH. This was also the case in Turkey and the UK, contributing to $40 \%$ and $38 \%$ of cases, respectively., ${ }^{9,10}$

Study by Temizkan et al showed increasing trend towards morbidly adherent placenta which may be attributed to increasing trends of primary caesarean sections.

The mortality amongst our patients was $2.2 \%$.

In $62 \%$ of the cases, subtotal hysterectomy was performed. It is not always possible to do total abdominal hysterectomy as the patients' general condition is often poor. Many reports and guidelines have advocated the preference for subtotal hysterectomy over total hysterectomy since it offers the advantage of less blood loss, fewer instances of damage to the urinary tract, and takes less time to complete in the face of hemodynamic compromise/instability. ${ }^{18,19}$ However, in cases of morbidly adherent placenta total hysterectomy may prove more beneficial as removal of the cervix leads to better hemostasis. ${ }^{20}$

Postoperative shock, pyrexia, paralytic ileus, and wound infection were common complications. Prolonged labor, intrauterine manipulation and dormant sepsis probably account for these complications. These could be prevented by early referral of these cases to wellequipped centers which can treat emergency obstetric cases promptly and efficiently.

\section{CONCLUSION}

Obstetric hysterectomy is a lifesaving procedure but decision should be prompt and treatment by an experienced surgeon. Every obstetrician should be trained to perform this procedure.

In conclusion, our results demonstrated an increasing trend in the rate of Obstetric hysterectomy in parallel with an increasing rate of previous LSCS, emphasizing the importance of the mode of delivery. Cesarean deliveries lead to repeat $\mathrm{CS}$, which increases the incidence of abnormal placentation and the risk of Obstetric hysterectomy. Because $\mathrm{OH}$ is associated with significant morbidity and mortality, to prevent repeats CS, vaginal delivery may be advised after CS deliveries. 
In spite of this life saving measure, there occurs significant number of maternal deaths which can be prevented by good maternal care, active management of labor, early recognition of complications, timely referral, and easy availability of transport and blood transfusion facilities.

Funding: No funding sources Conflict of interest: None declared

Ethical approval: The study was approved by the Institutional Ethics Committee

\section{REFERENCES}

1. Say L, Souza JP, Pattinson RC, WHO working group on Maternal Mortality and Morbidity classifications. Maternal near miss-towards a standard tool for monitoring quality of maternal health care. Best Pract Res Clin Obstet Gynaecol. 2009;23(3):287-96.

2. Miller S, Lester F, Hensleigh P. Prevention and treatment of postpartum hemorrhage: new advances for low-resource settings. J Midwifery Womens Health. 2004;49(4):283-92.

3. Singhal S, Singh A, Raghunandan C, Gupta U, Dutt S. Uterine artery embolization: exploring new dimensions in obstetric emergencies. Oman Med J. 2014;29(3):217219.

4. Varghese S, Gokulam N. Al-Abri S. Uterine Artery Embolization in Postpartum Hemorrhage: A Case Report. Oman Med J. 2012;27(2) .

5. Say L, Chou D, Gemmill A, Tunçalp Ö, Moller AB, Daniels $\mathrm{J}$, et al. Global causes of maternal death: a WHO systematic analysis. Lancet Glob Health. 2014;2(6):e323-e333.

6. Cameron CA, Roberts CL, Olive EC, Ford JB, Fischer WE. Trends in postpartum haemorrhage. Aust N Z J Public Health. 2006;30(2):151-6.

7. Tunçalp O, Hindin MJ, Souza JP, Chou D, Say L. The prevalence of maternal near miss: a systematic review. BJOG. 2012;119(6):653-61.

8. Durfee RB. Evolution of cesarean hysterectomy. Clin Obstet Gynecol. 1969;12(3):575-89.

9. Tapisiz OL, Altinbas SK, Yirci B, Cenksoy P, Kaya $\mathrm{AE}$, Dede $\mathrm{S}$. Emergency peripartum hysterectomy in a tertiary hospital in Ankara, Turkey: A 5-year review. Arch Gynecol Obstet. 2012;286(5):1131-4.

10. Knight M, UKOSS. Peripartum hysterectomy in the UK: management and outcomes of the associated haemorrhage. BJOG. 2007;114(11):1380-7.

11. Forna F, Miles AM, Jamieson DJ. Emergency peripartum hysterectomy: a comparison of cesarean and postpartum hysterectomy. Am J Obstet Gynecol. 2004;190:1440-4.

12. Kant A, Wadhwani K. Emergency obstetric hysterectomy J Obstet Gynecol India. 2005;55:132-4.

13. Ahmad SN, Mir IH. Emergency Peripartum Hysterectomy: Experience at apex hospital of Kashmir
Valley. The internet journal of gynecology and obstet. 2007;8:2.

14. Marwaha P, Kaur M, Gupta A. Peripartum Hysterectomy- a five years study. J Obstet Gynecol India. 2008;58:504-6.

15. Flood K, Said S, Geary M. Changing trends in peripartum hysterectomy over the last 4 decades Presented at the $28^{\text {th }}$ Annual Scientific Meeting of the Society for Maternal-Fetal Medicine, Dallas, TX, 2008.

16. Sharma R, Shaheen, Pathak J. Peripartum Hysterectomy-A review of 70 cases. South Asian Fedration of obstet and gynaecol. 2009;1(2):19-21.

17. Temizkan O, Angın D, Karakuş R. Changing trends in emergency peripartum hysterectomy in a tertiary obstetric center in Turkey during 2000-2013. J Turk Ger Gynecol Assoc. 2016;17(1):26-34.

18. Greer I, Lang G, Patel N. The Management of Postpartum Haemorrhage. Aberdeen: Scottish Obstetric Guidelines and Audit Project. 1998.

19. Roopnarinesingh R, Fay L, McKenna P. A 27-year review of obstetric hysterectomy. J Obstet Gynaecol. 2003;23(3):252-4.

20. Langdana F, Geary M, Haw W, Keane D. Peripartum hysterectomy in the 1990s: any new lessons? J Obstet Gynaecol. 2001;21(2):121-3.

21. Umezurike CC, Feyi-Waboso PA, Adisa CA. Peripartum hys- terectomy in Aba southeastern Nigeria. Aust N Z J Obstet Gynaecol. 2008;48:580-2.

22. Zeteroglu S, Ustun Y, Engin-Ustun Y, Sahin G, Kamaci M. Peripartum hysterectomy in a teaching hospital in the eastern region of Turkey. Eur J Obstet Gynecol Reprod Biol. 2005;120:57-62.

23. Yalcinkaya A, Guzel AI, Kangal K. Emergency peripartum hysterectomy: 16-year experience of a medical hospital. J Chin Med Assoc. 2010;73:360-3.

24. Demirci O, Tugrul AS, Yilmaz E, Tosun O, Demirci E, Eren YS. Emergency peripartum hysterectomy in a tertiary obstetric center: nine years evaluation. J Obstet Gynaecol Res. 2011;37:1054-60.

25. Publications Committee, Society for Maternal-Fetal Medicine. Belfort MA. Placenta accreta. Am J Obstet Gynecol. 2010;203:430-9.

26. Ding DC, Hsu S, Chu TW, Chu TY. Emergency peripartum hysterectomy in a teaching hospital in Eastern Taiwan. J Obstet Gynaecol. 2006;26:635-8.

27. Seffah JD. Re-laparatomy after cerarean section. Int J Gynaecol Obstet. 2005;88:253-7.

28. Knight M, Callaghan WM, Berg C, Alexander S, Bouvier-Colle MH, Ford JB. Trends in postpartum hemorrhage in high resource countries: a review and recommendations from the International Postpartum Hemorrhage Collaborative Group. BMC Pregnancy Childbirth. 2009;9:55.

Cite this article as: Shirodker SD, Pandey A, Yadav S. Emergency obstetric hysterectomy: review at a tertiary care hospital. Int J Reprod Contracept Obstet Gynecol 2016;5:3811-4. 